\title{
PENGARUH ATMOSFER TOKO, KESESUAIAN HARGA TERHADAP KEPUTUSAN PEMBELIAN KONSUMEN PADA TEMDAY STORE DENPASAR
}

\author{
Handy Surya Jaya ${ }^{1}$ \\ Gede Suparna ${ }^{2}$
}

\author{
${ }^{1,2}$,Fakultas Ekonomi dan Bisnis Universitas Udayana, Bali, Indonesia \\ e-mail: handy_surya8@yahoo.com
}

\begin{abstract}
ABSTRAK
Keputusan pembelian merupakan proses dimana konsumen melakukan penilaian terhadap berbagai alternatif pilihan dan memilih salah satu atau lebih alternatif yang diperlukan berdasarkan pertimbangan-pertimbangan tertentu. Penelitian ini bertujuan untuk menguji pengaruh atmosfer toko dan kesesuaian harga terhadap keputusan pembelian konsumen pada temday store Denpasar. Jumlah sampel yang diambil sebanyak 90 responden, dengan menggunakan metode purposive sampling. Pengumpulan data dilakukan dengan penyebaran kuisioner. Teknik analisis yang digunakan adalah teknik analisis regresi linear berganda. Berdasarkan hasil analisis menunjukan bahwa atmosfer toko berpengaruh positif dan signifikan terhadap keputusan pembelian. Kesesuaian harga berpengaruh positif dan signifikan terhadap keputusan pembelian. Untuk meningkatkan keputusan pembelian pada Temday Store Denpasar, disarankan dengan menambah fasilitas pembayaran sehingga mempermudah konsumen melakukan transaksi pembayaran dan mempertahankan kebersihan ruangan agar konsumen merasa nyaman serta menawarkan harga yang sesuai dan terjangkau pada suatu produk sehingga dapat mendorong konsumen melakukan keputusan pembelian.
\end{abstract}

Kata Kunci: atmosfer toko, kesesuaian harga, keputusan pembelian

\begin{abstract}
Purchase decisions is the process by which consumers make an assessment of the various alternative options and choose one or more alternatives are needed based on certain considerations. Study aimed to examine the effect of stores atmospheric and prices suitability on consumer purchase decisions at Temday Store Denpasar. Samples are taken by 90 respondents, using purposive sampling method. Data collection is done by distributing questionnaires. Analysis technique was multiple linear regression analysis. Based on the results of the analysis showed that the store atmosphere has positive and significant effect on purchase decisions. Price suitability positive and significant impact on purchase decisions. To improve purchase decisions at Temday Store Denpasar, Temday Store needs to add a payment facility that make consumers easier on payment transactions and maintain the cleanliness the room so that consumers feel comfortable and offers affordable prices of products to encourage consumers make purchase decisions.
\end{abstract}

Keywords: shops atmospheric, affordable price, purchase decision 


\section{PENDAHULUAN}

Situasi pasar saat ini banyak dipengaruhi oleh berbagai macam produk dari berbagai merek, baik itu merek yang sudah terkenal atau merek yang baru muncul sehingga terjadi persaingan diantara produsen. Melihat kondisi persaingan tersebut, setiap pelaku bisnis perlu meningkatkan kekuatan yang ada dalam perusahaannya dengan cara memunculkan perbedaan atau keunikan yang dimiliki perusahaan dibandingkan dengan pesaing untuk dapat menarik minat beli konsumen.

Saat ini, tugas seorang pemasar menjadi makin sulit dan kompleks. Dikatakan demikian karena disatu sisi kebutuhan dan keinginan konsumen makin beragam dan menuntut kepuasan yang makin tinggi terhadap produk - produk yang dibelinya. Melisa (2012) menyatakan bahwa, untuk dapat bertahan dan berkembang sebuah perusahaan perlu memahami perilaku konsumen agar mampu menimbulkan pembelian ulang konsumen sehingga pada akhirnya dapat bersaing dengan perusahaan lainnya. Disinilah banyak muncul strategi bagaimana agar suatu produk dari merek tertentu dapat diterima oleh konsumen dengan baik, karena setiap konsumen mempunyai cara pandang yang berbeda - beda terhadap suatu produk tertentu. Terdapat sebagian dari konsumen yang setia pada satu produk dari merek tertentu, ada pula konsumen yang suka mencoba - coba terhadap berbagai macam produk baru dari berbagai merek. Bagi perusahaan yang berorientasi laba jangka panjang, pasar adalah fokus utama yang menjadi perhatiannya. Pemasar sangat berkepentingan untuk menggambarkan pasarnya berdasarkan variabel atau karakteristik, seperti karakteristik demografis dan sosial 
ekonomi, namun karakteristik itu hanya menggambarkan konsumen secara deskriptif yang memberi jawaban untuk pertanyaan siapa dan dimana mereka.

Menurut Fuad (2009), salah satu strategi pemasaran pada toko adalah pendesainan atmosfer toko. Perancangan tersebut dilakukan diantaranya untuk dapat menarik konsumen, memicu pembelian oleh konsumen, menciptakan suasana yang dapat mempengaruhi emosi konsumen, dan untuk dapat mempengaruhi bagaimana konsumen berperilaku. Menurut Peter dan Olson (dalam Fuad, 2009) menyatakan bahwa tiga keputusan utama dalam mendesain lingkungan fisik suatu usaha adalah lokasi, tata letak, serta rangsangan atau atmosfer yang ditimbulkannya. Harapan yang dimiliki seorang konsumen belum tentu akan mendorong konsumen yang bersangkutan untuk melakukan pembelian. Harapan tersebut harus mampu distimulir sehingga timbulnya tekanan untuk segera mewujudkannya dalam bentuk tindakan pembelian. Terdapat bermacam faktor yang dapat menjadi stimulus, antara lain adalah atmosfer toko. Pihak manajemen toko dapat mendesain atmosfer toko sebaik mungkin agar dapat menimbulkan rasa nyaman dan aman didalam diri konsumen sehingga mendorong konsumen untuk melaksanakan keputusan pembeliannya. Atmosfer toko juga dapat dijadikan sebagai salah satu alat pemasaran untuk dapat menarik konsumen untuk datang, menikmati suasana toko sampai melakukan keputusan pembelian seperti apa yang telah disimpulkan oleh (Meldarianda dan Lisan, 2010) dalam penelitiannya. Atmosfer toko tidak hanya dapat memberikan suasana lingkungan pembelian yang menyenangkan saja, tetapi juga dapat memberikan nilai tambah terhadap produk yang dijual. Atmosfer toko juga akan menentukan citra toko itu 
sendiri. Karmela dan Junaedi (2009) dalam penelitiannya menyatakan atmosfer toko yang baik dan menyenangkan juga akan dapat menjaga dan mendorong citra perusahaan. Citra toko yang baik dapat menjamin kelangsungan hidup perusahaan untuk bertahan terhadap persaingan dalam membentuk pelanggan yang loyal, sama halnya dengan atmosfer toko dapat membuat konsumen untuk lebih loyal (Chen dan Hsieh, 2011). Atmosfer toko sebagai salah satu sarana komunikasi yang dapat berakibat positif dan menguntungkan dibuat semenarik mungkin untuk menciptakan kenyamanan bagi konsumen, minimal konsumen akan merasa betah di toko tersebut dan hal ini akan membuat konsumen untuk memutuskan pembelian di toko tersebut. Jika konsumen sudah merasa puas berbelanja ditempat tersebut, kemungkinan besar konsumen tersebut akan berbelanja kembali.

Lubis dan Martin (2009) mengemukakan banyak faktor yang mempengaruhi keputusan pembelian salah satunya adalah faktor harga. Harga sangat mempengaruhi keputusan pembelian konsumen di suatu tempat. Kenesei dan Todd (2003) mengemukakan bahwa harga adalah biaya terbaik pembeli yang dapat menentukan dan memainkan peran penting dalam keputusan mereka. Harapan agar pelanggan setia atau loyal terhadap produk - produk yang ditawarkan membuat pemasar harus memahami perilaku mereka. Sangat penting bagi pemasar dan calon pemasar untuk memahami mengapa dan bagaimana individu atau organisasi membuat keputusan pembeliannya sehingga memungkinkannya untuk membuat keputusan pemasaran strategis yang lebih baik (Suprapti, 2010:6). 
Bahri (2011) mengemukakan secara teoritis keputusan pembelian yang dilakukan oleh konsumen terhadap barang yang ditawarkan sangat dipengaruhi oleh harga, pelayanan, atmosfer kenyamanan, keragaman produk dan desain toko. Temday Store merupakan distro yang memiliki konsep sedikit berbeda dari distrodistro lainnya. Temday Store menjual merchandise musik dan band baik itu $t$ shirt, hoodie, topi, tas, audio disc (cd) dan dvd yang langsung diimport dari official resmi band dan musik tersebut. Selain merchandise band dan musik, Temday Store juga menjual beberapa merchandise dari brand skateboard dan merchandise dari brand yang merilis hasil karya seniman tattoo mancanegara serta beberapa macam pomade dari berbagai merek. Produk-produk yang disediakan oleh Temday Store memiliki harga yang cukup mahal dibandingkan dengan distro lainnya, karena semua barang langsung diimport dari luar, namun memiliki kualitas yang baik. Desain toko juga terlihat cukup unik dengan memajang beberapa poster band serta musik yang diputar didalam toko juga dapat menstimulus konsumen sehingga lebih nyaman dalam memilih barang. Pasar sasaran Temday Store meliputi konsumen remaja hingga dewasa yang cenderung penikmat dan suka bermain musik. Sebagai salah satu toko yang menjual merchandise band, akan tetapi masih banyak konsumen yang hanya berkunjung tetapi tidak melakukan pembelian karena harga yang cukup mahal. Kurang strategisnya lokasi toko yang jauh dari pusat keramaian juga mengindikasikan bahwa Temday Store susah untuk dijangkau banyak orang.

Berdasarkan latar belakang yang telah diuraikan sebelumnya, maka rumusan masalah penelitian ini adalah sebagai berikut: 1) Bagaimana pengaruh 
atmosfer toko terhadap keputusan pembelian konsumen pada Temday Store Denpasar?; 2) Bagaimana pengaruh kesesuaian harga terhadap keputusan pembelian konsumen pada Temday Store Denpasar?

Berdasarkan uraian latar belakang dan rumusan masalah, maka dirumuskan tujuan penelitian sebagai berikut : 1) Untuk mengetahui pengaruh atmosfer toko terhadap keputusan pembelian konsumen pada Temday Store Denpasar; 2) Untuk mengetahui pengaruh kesesuaian harga terhadap keputusan pembelian konsumen pada Temday Store Denpasar.

Schiffman dan Kanuk (2008:485) mendefinisikan suatu keputusan sebagai seleksi terhadap dua pilihan alternatif atau lebih. Kotler dan Armstrong (2008:181) keputusan pembelian konsumen adalah membeli merek yang paling disukai, tetapi dua faktor bisa berada antara niat pembelian dan keputusan pembelian. Karakteristik pembeli dan proses pengambilan keputusan menimbulkan keputusan pembelian tertentu. Tugas pemasar adalah memahami apa yang terjadi dalam kesadaran pembeli mulai dari adanya rangsangan dari luar hingga munculnya keputusan pembelian konsumen (Irawan, 2010). Dapat disimpulkan bahwa pengambilan keputusan konsumen adalah suatu proses pemilihan salah satu dari beberapa alternatif penyelesaian masalah yang dikumpulkan oleh seorang konsumen dan mewujudkannya dengan tindak lanjut yang nyata (Irawan, 2010).

Kotler dan Armstrong (2008:179) proses keputusan pembelian terdiri dari lima tahap, yaitu: 1) Pengenalan kebutuhan, sebelum konsumen melakukan tahap pemilihan dan keputusan pembeliannya, konsumen wajib mengenali masalah atau 
kebutuhannya yang dapat timbul melalui rangsangan internal dan eksternal. Para pemasar perlu mengidentifikasi keadaan yang memicu kebutuhan tertentu agar dapat mengumpulkan informasi dari sejumlah konsumen sehingga para pemasar dapat mengidentifikasi rangsangan yang paling sering membangkitkan minat konsumen akan suatu produk tertentu. Pemasar kemudian dapat menyusun strategi pemasaran yang baik sehingga mampu memicu minat konsumen. 2) Pencarian informasi, konsumen yang terangsang kebutuhannya akan melakukan pencarian informasi yang lebih banyak yang berkaitan dengan kebutuhan konsumen itu sendiri sehingga yang menjadi perhatian utama pemasar adalah sumber-sumber informasi utama yang menjadi acuan konsumen dan pengaruh tiap sumber tersebut terhadap keputusan pembelian selanjutnya. 3) Evaluasi alternatif, terdapat beberapa proses evaluasi keputusan dan model-model yang terbaru memandang proses evaluasi konsumen sebagai proses yang berorientasi kognitif, yaitu model tersebut menganggap konsumen membentuk kriteria tertentu atas produk dengan sangat sadar dan rasional. Beberapa konsep dapat membantu memahami proses evaluasi konsumen. Pertama, konsumen selalu berusaha untuk dapat memenuhi kebutuhannya. Kedua, konsumen mencari manfaat tertentu dari suatu produk. Ketiga, konsumen memandang setiap produk sebagai sekumpulan atribut dengan kemampuan yang berbeda-beda dalam memberikan manfaat yang digunakan untuk memuaskan kebutuhan itu. 4) Keputusan pembelian, dalam tahap evaluasi, konsumen biasanya membentuk preferensi atas produk-produk yang ada di dalam kumpulan pilihan. Konsumen tersebut juga dapat membentuk niat untuk membeli 
produk yang paling disukai. 5) Perilaku pasca pembelian, setelah membeli produk, konsumen akan mengalami level kepuasan atau ketidakpuasan tertentu.

Berman dan Evans (dalam Putra, 2001:604) atmosfer toko dibagi kedalam beberapa dimensi, yaitu: 1) Exterior, karakteristik exterior memiliki pengaruh yang kuat pada citra toko sendiri, sehingga harus dibuat sebaik mungkin. Kombinasi dari exterior ini dapat membuat bagian luar toko menjadi terlihat menarik, menonjol, unik dan memicu konsumen untuk berkunjung ke dalam toko. 2) General Interior, dari suatu toko harus dirancang untuk memaksimalkan visual merchandising. Suasana toko yang baik dapat menarik konsumen untuk berkunjung ke toko. Namun, hal yang paling utama yang dapat membuat penjual menarik konsumen setelah berada di toko adalah display. Display yang baik harus dapat menarik perhatian konsumen dan membantu mereka agar mudah mengatasi, memeriksa dan memilih produk-produk dan akhirnya melakukan keputusan pembelian. Ketika konsumen berada didalam toko ada banyak faktor yang akan mempengaruhi persepsi mereka pada toko tersebut. 3) Store Layout, meliputi penataan ruangan untuk mengisi ruang yang tersedia agar terlihat rapi dan menarik, membagi produk yang akan ditawarkan berdasarkan manfaatnya atau jenis produk itu sendiri, pengaturan lalu lintas didalam toko agar konsumen merasa nyaman saat memilih barang, pengaturan lebar ruang yang dibutuhkan, pemetaan ruangan toko dan menyusun produk yang ditawarkan agar mudah dicari oleh konsumen. 4) Interior Display, poster, papan petunjuk, dan ragam interior display lainnya dapat mempengaruhi atmosfer toko, karena memberikan informasi 
bagi konsumen. Selain memberikan informasi bagi konsumen, interior display juga dapat merangsang konsumen untuk melakukan keputusan pembelian.

Atmosfer toko menurut Lamb et al. (dalam Putra, 2001:105) adalah suatu keseluruhan yang disampaikan oleh tata letak fisik, dekorasi dan lingkungan sekitarnya. Menurut Gilbert (dalam Putra, 2003:129) atmosfer toko merupakan kombinasi dari pesan secara fisik yang telah direncanakan. Atmosfer toko dapat digambarkan sebagai perubahan terhadap perencanaan lingkungan pembelian yang menghasilkan efek emosional khusus yang dapat menyebabkan konsumen melakukan tindakan pembelian. Atmosfer toko juga telah menjadi pusat diskusi baru sebagai sarana untuk menciptakan pengalaman konsumsi yang menyenangkan (Hedrick et al., 2002).

Menurut Nofiawaty dan Yuliandi (2014) menyatakan bahwa hasil analisis menunjukan atmosfer toko mempunyai pengaruh yang signifikan terhadap keputusan pembelian. Penelitian yang dilakukan oleh Melisa (2012) menyatakan bahwa hasil analisis menunjukan desain dan tampilan toko berpengaruh signifikan terhadap keputusan pembelian ulang konsumen. Penelitian lain yang mendukung dilakukan oleh Hadi (2004) menunjukan bahwa atmosfer toko berpengaruh positif dan signifikan terhadap keputusan pembelian. Berdasarkan landasan teori dan pembahasan hasil penelitian sebelumnya, maka dapat dikemukakan hipotesis yaitu:

$\mathrm{H}_{1}$ : Atmosfer Toko berpengaruh positif terhadap Keputusan Pembelian Konsumen pada Temday Store Denpasar.

Menurut Kotler dan Armstrong (2008:345) harga adalah jumlah yang ditagihkan atas suatu produk atau jasa. Lebih luas lagi, harga adalah jumlah semua 
nilai yang diberikan oleh pelanggan untuk mendapatkan keuntungan dari memiliki atau menggunakan suatu produk atau jasa. Menurut Swasta dan Sukotjo (2002:211) harga adalah sejumlah uang yang dibutuhkan untuk mendapatkan sejumlah kombinasi dari barang atau jasa beserta pelayanannya. Harga juga dapat menjadi bahan pertimbangan bagi konsumen untuk pengambilan keputusan dalam membeli (Suti, 2010).

Strategi penetapan harga menurut Kotler dan Armstrong (2008:6) yaitu: 1) Penetapan harga lini produk (product line pricing), menetapkan tingkatantingkatan harga antara berbagai produk dalam sebuah lini produk berdasarkan perbedaan biaya antara produk, evaluasi pelanggan terhadap sifat-sifat yang berbeda dan harga pesaing. 2) Penetapan harga produk pilihan (optional product pricing), penetapan harga dari produk pilihan ataupun pelengkap bersama produk utama. 3) Penetapan harga produk terikat (captive product pricing), menetapkan suatu harga untuk produk-produk yang harus digunakan bersama satu produk utama. 4) Penetapan harga produk sampingan (by product pricing), menetapkan harga untuk produk sampingan dengan maksud membuat harga produk utama lebih kompetitif. 5) Penetapan harga paket produk (product bundle pricing), menggabungkan beberapa produk dan menawarkan paket tersebut pada harga yang lebih rendah.

Menurut Kotler dan Armstrong (2008:9) perusahaan biasanya menyesuaikan harga dasar mereka untuk memperhitungkan perbedaan pelanggan dan perubahan situasi. Beberapa penyesuaian harga diantaranya: 1) Penetapan harga diskon dan potongan harga, mengurangi harga untuk memberikan penghargaan kepada 
pelanggan yang memberikan tanggapan seperti membayar lebih awal atau mempromosikan produk. 2) Penetapan harga tersegmentasi, menyesuaikan harga untuk membuat perbedaan diantara produk, pelanggan maupun lokasi. 3) Penetapan harga psikologis, menyesuaikan harga untuk mempengaruhi secara psikologis. 4) Penetapan harga promosi, sewaktu-waktu mengurangi harga untuk meningkatkan penjualan dalam jangka pendek. 5) Penetapan harga geografis, menyesuaikan harga untuk memperhitungkan lokasi geografis pelanggan. 6) Penetapan harga dinamis, menyesuaikan harga terus menerus untuk memenuhi karakteristik dan kebutuhan pelanggan individual dan situasi. 7) Penetapan harga internasional, menyesuaikan harga untuk pasar tradisional.

Menurut Hariadi dan Martoatmodjo (2013) menunjukan bahwa kesesuaian harga berpengaruh positif terhadap keputusan pembelian konsumen. Penelitian yang dilakukan oleh Wibowo dan Karimah (2012) menyatakan bahwa harga memiliki pengaruh positif terhadap keputusan pembelian konsumen. Purwati dkk. (2012) menyatakan bahwa hasil analisis menunjukan harga berpengaruh signifikan terhadap keputusan pembelian konsumen. Berdasarkan landasan teori dan pembahasan hasil penelitian sebelumnya, maka dapat dikemukakan hipotesis yaitu:

$\mathrm{H}_{2}$ : Kesesuaian Harga berpengaruh positif terhadap Keputusan Pembelian Konsumen pada Temday Store Denpasar. 


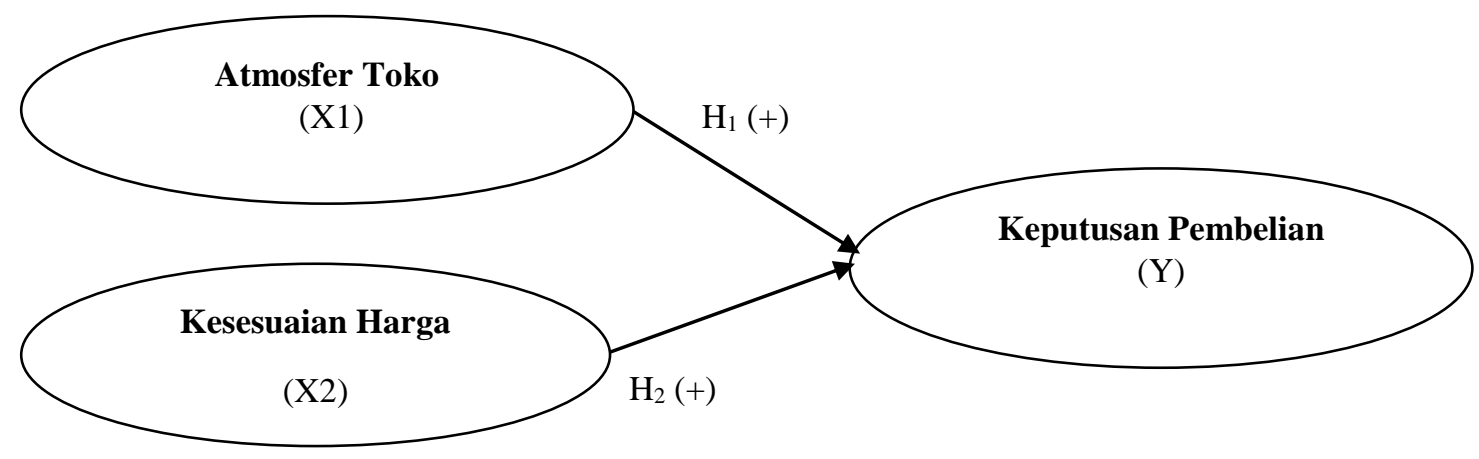

Gambar 1. Kerangka Konseptual

\section{METODE PENELITIAN}

Penelitian ini termasuk dalam golongan penelitian asosiatif. Penelitian yang bertujuan untuk mengetahui pengaruh atau juga hubungan antara dua variabel atau lebih. Variabel dependent yang digunakan dalam penelitian ini adalah keputusan pembelian, sedangkan variabel independent adalah atmosfer toko dan kesesuaian harga. Penelitian ini dilakukan pada Temday Store yang beralamat di JL. Nangka Selatan no 127 Denpasar. Metode pengumpulan data dilakukan dengan metode survey dengan teknik wawancara menggunakan kuesioner.

Populasi dalam penelitian ini adalah jumlah konsumen yang pernah berbelanja di Temday Store. Penentuan sampel ditetapkan dengan menggunakan 5-10 kali dari jumlah variabel atau indikator (Sugiyono, 2014:130). Indikator yang digunakan dalam penelitian ini adalah 15 indikator, sehingga banyaknya responden yang digunakan sebagai sampel dalam penelitian ini adalah 90 responden. Sampel dalam penelitian ini ditentukan dengan teknik purposive sampling.

Butir - butir pernyataan yang digunakan dalam kuisioner diukur dengan menggunakan skala likert yang dimana 1 berarti sangat tidak setuju dan 5 berarti 
sangat setuju. Untuk variabel atmosfer toko digunakan 10 indikator. Untuk variabel kesesuaian harga digunakan 2 indikator. Untuk variabel keputusan pembelian digunakan 3 indikator. Selanjutnya data akan diolah menggunakan teknik analisis regresi linear berganda dengan menggunakan program SPSS 13.00 for windows. Model regresi linear berganda sebagai berikut (Wirawan, 2002:293).

$$
\mathrm{Y}=\alpha+\beta_{1} \mathrm{X}_{1}+\beta_{2} \mathrm{X}_{2}+\mu
$$

Keterangan:

$$
\begin{array}{ll}
\mathrm{Y} & =\text { Keputusan Pembelian } \\
\alpha & =\text { Bilangan Konstanta } \\
\mathrm{x}_{1} & =\text { Atmosfer Toko } \\
\mathrm{x}_{2} & =\text { Kesesuaian Harga }
\end{array}
$$

Indikator variabel atmosfer toko ini diukur dengan indikator berikut: 1) Store Front. 2) Marquee. 3) Parkir (Parking). 4) Pencahayaan (Lighting). 5) Musik (Sounds). 6) Karyawan (Personal). 7) Barang Dagangan (Merchandise). 8) Technology / Modernization. 9) Kebersihan (Cleanliness). 10) Rack displays. Indikator variabel kesesuaian harga dapat diukur dengan indikator berikut: 1) Keterjangkauan harga. 2) Kesesuaian harga dengan kualitas produk. Indikator variabel keputusan pembelian dapat diukur dengan indikator berikut: 1) Kemantapan pada sebuah produk. 2) Memberikan rekomendasi kepada orang lain. 3) Melakukan pembelian ulang. 
HASIL DAN PEMBAHASAN

Tabel 1.

Karakteristik Responden Berdasarkan Jenis Kelamin

\begin{tabular}{llcc}
\hline No. & Jenis Kelamin & $\begin{array}{c}\text { Jumlah responden } \\
\text { (orang) }\end{array}$ & $\begin{array}{c}\text { Persentase } \\
\text { (persen) }\end{array}$ \\
\hline 1. & Laki-Laki & 85 & 94,44 \\
2. & Perempuan & 5 & 5,56 \\
\hline & Jumlah & 90 & 100 \\
\hline
\end{tabular}

Sumber: Data diolah, 2016

Tabel 1, menunjukkan bahwa jumlah responden berjenis kelamin laki-laki sebanyak 85 orang atau 94,44 persen dan perempuan sebanyak 5 orang atau 5,56 persen. Hal ini menunjukkan bahwa sebagian besar pelanggan pada Temday Store Denpasar berjenis kelamin laki-laki, karena hampir seluruh produk yang dijual di Temday Store merupakan produk untuk laki-laki.

Tabel 2.

\section{Karakteristik Responden Berdasarkan Umur}

\begin{tabular}{lccc}
\hline No. & Umur & Jumlah responden (orang) & Persentase (persen) \\
\hline 1 & $15-20$ & 36 & 40,00 \\
2 & $21-25$ & 41 & 45,56 \\
3 & $26-30$ & 10 & 11,11 \\
4 & $31-35$ & 3 & 3,33 \\
\hline & & 90 & 100 \\
\hline
\end{tabular}

Sumber: Data diolah, 2016

Tabel 2, menunjukkan responden dalam penelitian ini memiliki umur berkisar 15 - 20 tahun sebanyak 36 orang atau sebesar 40,00 persen, umur $21-25$ tahun sebanyak 41 orang atau sebesar 45,56 persen, umur 26 - 30 sebanyak 10 orang atau sebesar 11,11 persen, dan umur 31 - 35 sebanyak 3 orang atau 3,33 persen. Hal ini menunjukan bahwa sebagian besar konsumen yang berbelanja di 
Temday Store adalah anak muda usia antara $21-25$, karena produk yang ditawarkan oleh Temday Store memang menyasar pada anak muda.

Tabel 3.

Karakteristik Responden Berdasarkan Tingkat Pendidikan

\begin{tabular}{clcc}
\hline No. & Pekerjaan & $\begin{array}{c}\text { Jumlah responden } \\
\text { (orang) }\end{array}$ & $\begin{array}{c}\text { Persentase } \\
\text { (Persen) }\end{array}$ \\
\hline 1. & SMA & 30 & 33,33 \\
2. & Diploma & 35 & 38,89 \\
3. & S1 & 25 & 27,78 \\
\hline & Jumlah & 90 & 100 \\
\hline
\end{tabular}

Sumber: Data diolah, 2016

Tabel 3, menunjukkan jumlah responden mayoritas mempunyai tingkat pendidikan Diploma sebanyak 35 orang atau sebesar 38,89 persen, pendidikan SMA sebanyak 30 orang atau sebesar 33,33 persen dan S1 sebanyak 25 orang atau sebesar 27,78 persen.

Menurut Ghozali (2010:49) uji validitas digunakan untuk mengukur sah atau tidaknya suatu kuesioner, dimana pernyataan kuesioner sudah betul-betul dapat mengukur apa yang hendak diukur. Pada dasarnya validitas ini berfungsi untuk mengukur atau menguji apakah tiap-tiap butir instrumen telah benar-benar menggungkapkan indikator yang ingin diteliti. Uji validitas digunakan untuk memeriksa apakah kuesioner sudah tepat untuk mengukur apa yang ingin diukur dan cukup dipahami oleh semua responden yang diindikasikan oleh kecilnya presentase jawaban responden yang tidak terlalu menyimpang dari jawaban responden lainnya.

Tabel 4, menunjukkan bahwa keseluruhan indikator yang digunakan memiliki nilai korelasi diatas 0,3 sehingga keseluruhan indikator yang digunakan dinyatakan valid dan dapat dilanjutkan ke analisa berikutnya. 
Tabel 4.

Hasil Uji Validitas

\begin{tabular}{llccc}
\hline No & Variabel & Indikator & Koefisien Korelasi & Keterangan \\
\hline 1. & Atmosfer Toko & X1.1 & 0,731 & Valid \\
& & X1.2 & 0,762 & Valid \\
& & X1.3 & 0,674 & Valid \\
& & X1.4 & 0,858 & Valid \\
& & X1.5 & 0,738 & Valid \\
& & X1.6 & 0,780 & Valid \\
& & X1.7 & 0,662 & Valid \\
& & X1.8 & 0,767 & Valid \\
& & X1.9 & 0,807 & Valid \\
& & X1.10 & 0,801 & Valid \\
2. & Kesesuaian Harga & X2.1 & 0,934 & Valid \\
& & X2.2 & 0,934 & Valid \\
3. & Keputusan Pembelian & Y1.1 & 0,844 & Valid \\
& & Y1.2 & 0,861 & Valid \\
& & Y1.3 & 0,872 & Valid \\
\hline
\end{tabular}

Sumber: Data diolah, 2016

Pengujian reliabilitas atau keandalan instrumen menunjukkan sejauh mana suatu pengukuran kembali terhadap gejala yang sama. Instrumen yang reliabel adalah instrumen yang digunakan beberapa kali untuk mengukur objek yang sama akan menghasilkan data atau jawaban yang sama pula. Instrumen dikatakan handal apabila memiliki cronbach's alpha lebih dari 0,60 (Sugiyono, 2014:172).

Tabel 5.

Hasil Uji Reliabilitas

\begin{tabular}{lcl}
\hline \multicolumn{1}{c}{ Variabel } & Cronbach's Alpha & Keterangan \\
\hline Atmosfer Toko & 0,918 & Reliabel \\
Kesesuaian Harga & 0,854 & Reliabel \\
Keputusan Pembelian & 0,821 & Reliabel \\
\hline
\end{tabular}

Sumber: Data diolah, 2016

Tabel 5, menunjukkan seluruh instrumen penelitian dikatakan reliabel dimana keseluruhan instrumen layak digunakan untuk mengumpulkan data. Nilai keseluruhan cronbach'salpha $\geq 0,6$ menunjukkan bahwa pengukuran tersebut dapat memberikan hasil yang konsisten. 
Tabel 6, menunjukan bahwa rata-rata dari sebelas penilaian dari variabel atmosfer toko memperoleh total nilai rata-rata sebesar 3,59 yang masuk dalam kriteria sangat tinggi. Nilai rata-rata tertinggi pada responden atmosfer toko ditunjukan pada penilaian "Tempat parkir yang ada di area Temday Store luas untuk memarkir kendaraan” dengan nilai rata-rata sebesar 3,66.

Selanjutnya nilai rata-rata terendah penilaian responden dari variabel atmosfer toko ditunjukan pada penilaian "Temday Store memudahkan konsumen untuk melakukan pembayaran.” dengan nilai rata-rata 3,49.

Tabel 6.

Penilaian Responden pada Variabel Atmosfer Toko

\begin{tabular}{|c|c|c|c|c|c|c|c|}
\hline \multirow{2}{*}{$\begin{array}{c}\text { Variabel } \\
\text { Atmosfer Toko }\end{array}$} & \multicolumn{5}{|c|}{ Klasifikasi Jawaban } & \multirow{2}{*}{$\begin{array}{l}\text { Total } \\
\text { Skor }\end{array}$} & \multirow{2}{*}{$\begin{array}{l}\text { Rata- } \\
\text { Rata } \\
\text { Skor }\end{array}$} \\
\hline & $\begin{array}{c}\text { STS } \\
1\end{array}$ & $\begin{array}{c}\text { TS } \\
2\end{array}$ & $\begin{array}{c}\text { CS } \\
3\end{array}$ & $\begin{array}{l}S \\
4\end{array}$ & $\begin{array}{c}\text { SS } \\
5\end{array}$ & & \\
\hline Bagian depan Temday Store unik membuat & & & & & & & \\
\hline $\begin{array}{l}\text { konsumen tertarik untuk masuk ke dalam } \\
\text { toko. }\end{array}$ & 0 & 4 & 30 & 51 & 5 & 327 & 3.63 \\
\hline Papan nama Temday Store terlihat jelas. & 0 & 1 & 36 & 51 & 2 & 324 & 3.60 \\
\hline $\begin{array}{l}\text { Tempat parkir yang ada di area Temday Store } \\
\text { luas untuk memarkir kendaraan. }\end{array}$ & 0 & 2 & 31 & 53 & 4 & 329 & 3.66 \\
\hline $\begin{array}{l}\text { Pencahayaan yang ada di Temday Store } \\
\text { memudahkan konsumen untuk memilih } \\
\text { produk. }\end{array}$ & 0 & 4 & 28 & 55 & 3 & 327 & 3.63 \\
\hline $\begin{array}{l}\text { Musik yang diputar di dalam Temday Store } \\
\text { membuat suasana berbelanja nyaman. }\end{array}$ & 0 & 2 & 42 & 42 & 4 & 318 & 3.53 \\
\hline $\begin{array}{l}\text { Pelayanan karyawan Temday Store } \\
\text { mempermudah konsumen dalam memilih } \\
\text { produk. }\end{array}$ & 0 & 3 & 38 & 46 & 3 & 319 & 3.54 \\
\hline $\begin{array}{l}\text { Produk yang ditawarkan Temday Store } \\
\text { berkualitas. }\end{array}$ & 0 & 1 & 37 & 48 & 4 & 325 & 3.61 \\
\hline Fasilitas pembayaran yang disediakan & & & & & & & \\
\hline $\begin{array}{l}\text { Temday Store memudahkan konsumen untuk } \\
\text { melakukan pembayaran. }\end{array}$ & 0 & 4 & 39 & 46 & 1 & 314 & 3.49 \\
\hline Ruangan didalam Temday Store bersih. & 0 & 2 & 33 & 50 & 5 & 328 & 3.64 \\
\hline $\begin{array}{l}\text { Display produk-produk di dalam Temday } \\
\text { Store menarik. }\end{array}$ & 0 & 4 & 38 & 45 & 3 & 317 & 3.52 \\
\hline Rata-ra & & & & & & & 3,59 \\
\hline
\end{tabular}

Sumber: Data diolah, 2016 
Tabel 7.

Penilaian Responden pada Variabel Kesesuaian Harga

\begin{tabular}{|c|c|c|c|c|c|c|c|}
\hline \multirow{3}{*}{$\begin{array}{c}\text { Variabel } \\
\text { Kesesuaian Harga }\end{array}$} & \multicolumn{5}{|c|}{ Klasifikasi Jawaban } & \multirow{3}{*}{$\begin{array}{l}\text { Total } \\
\text { Skor }\end{array}$} & \multirow{3}{*}{$\begin{array}{l}\text { Rata } \\
\text { Rata } \\
\text { Skor }\end{array}$} \\
\hline & STS & TS & CS & $\mathbf{S}$ & SS & & \\
\hline & 1 & 2 & 3 & 4 & 5 & & \\
\hline $\begin{array}{l}\text { Harga produk-produk yang } \\
\text { ditawarkan di Temday Store } \\
\text { terjangkau. }\end{array}$ & 0 & 5 & 34 & 49 & 2 & 318 & 3.53 \\
\hline $\begin{array}{l}\text { Harga produk di Temday Store } \\
\text { sesuai dengan kualitas produk itu } \\
\text { sendiri. }\end{array}$ & 0 & 1 & 38 & 48 & 3 & 323 & 3.59 \\
\hline & Rata- & & & & & & 3,56 \\
\hline
\end{tabular}

Sumber: Data diolah, 2016

Tabel 7, menunjukan bahwa rata-rata dari kedua penilaian dari variabel kesesuaian harga memperoleh total nilai rata-rata sebesar 3,56 yang masuk dalam kriteria sangat tinggi. Nilai rata-rata tertinggi pada responden kesesuaian harga ditunjukan pada penilaian "Harga produk di Temday Store sesuai dengan kualitas produk itu sendiri” dengan nilai rata-rata sebesar 3,59.

Selanjutnya nilai rata-rata terendah penilaian responden dari variabel kesesuaian harga ditunjukan pada penilaian "Harga produk-produk yang ditawarkan di Temday Store terjangkau" dengan nilai rata-rata 3,53.

Tabel 8, menunjukan bahwa rata-rata dari ketiga penilaian dari variabel keputusan pembelian memperoleh total nilai rata-rata sebesar 3,78 yang masuk dalam kriteria sangat tinggi. Nilai rata-rata tertinggi pada responden kesesuaian harga ditunjukan pada penilaian "Konsumen dengan terbiasa melakukan pembelian ulang di Temday Store" dengan nilai rata-rata sebesar 3,83.

Selanjutnya nilai rata-rata terendah penilaian responden dari variabel keputusan pembelian ditunjukan pada penilaian "Konsumen mendapatkan 
rekomendasi dari orang lain untuk berbelanja di Temday Store" dengan nilai ratarata 3,69.

Tabel 8.

Penilaian Responden pada Variabel Keputusan Pembelian

\begin{tabular}{|c|c|c|c|c|c|c|c|}
\hline \multirow{2}{*}{$\begin{array}{c}\text { Variabel } \\
\text { Keputusan Pembelian }\end{array}$} & \multicolumn{5}{|c|}{ Klasifikasi Jawaban } & \multirow{2}{*}{$\begin{array}{l}\text { Total } \\
\text { Skor }\end{array}$} & \multirow{2}{*}{$\begin{array}{l}\text { Rata- } \\
\text { Rata } \\
\text { Skor }\end{array}$} \\
\hline & $\begin{array}{c}\text { STS } \\
1\end{array}$ & $\begin{array}{c}\text { TS } \\
2\end{array}$ & $\begin{array}{c}\text { CS } \\
3\end{array}$ & $\begin{array}{l}S \\
4\end{array}$ & $\begin{array}{c}\text { SS } \\
5\end{array}$ & & \\
\hline $\begin{array}{l}\text { Konsumen yakin terhadap produk } \\
\text { yang disediakan oleh Temday } \\
\text { Store. }\end{array}$ & 0 & 1 & 19 & 65 & 5 & 344 & 3.82 \\
\hline $\begin{array}{l}\text { Konsumen mendapatkan } \\
\text { rekomendasi dari orang lain untuk } \\
\text { berbelanja di Temday Store. }\end{array}$ & 0 & 2 & 29 & 54 & 5 & 332 & 3.69 \\
\hline $\begin{array}{l}\text { Konsumen dengan terbiasa } \\
\text { melakukan pembelian ulang di } \\
\text { Temday Store. }\end{array}$ & 0 & 1 & 21 & 60 & 8 & 345 & 3.83 \\
\hline \multicolumn{7}{|c|}{ Rata-rata } & 3,78 \\
\hline
\end{tabular}

Sumber: Data diolah, 2016

Tabel 9.

Hasil Analisis Regresi Linear Berganda

\begin{tabular}{lccc}
\hline \multicolumn{1}{c}{ Nama Variabel } & $\begin{array}{c}\text { Koefisien } \\
\text { Regresi }\end{array}$ & t-test & Sig.t \\
\hline Atmosfer Toko & 0,122 & 3,641 & 0,000 \\
Kesesuaian Harga & 0,394 & 2,745 & 0,007 \\
Konstanta & & 0,000 & \\
R & & 0,640 & \\
R square & & 0,409 & \\
F hitung & & 30,132 & \\
F sig & 0,000 & \\
\hline Sumber: &
\end{tabular}

Sumber: Data diolah, 2016

Tabel 9, dapat dilihat bahwa besarnya nilai $\mathrm{R}$ square adalah sebesar 0,409

ini berarti pengaruh variabel atmosfer toko dan kesesuaian harga terhadap keputusan pembelian sebesar 40,9 persen sedangkan sisanya sebesar 59,1 persen dipengaruhi oleh variabel lain yang tidak masuk dalam model penelitian. 
Tabel 9, dapat dilihat nilai koefisien regresi dari variabel bebas atmosfer toko, kesesuaian harga dan konstanta variabel terikat keputusan pembelian, maka diperoleh persamaan regresi linear berganda sebagai berikut:

$$
\mathrm{Y}=4,154+0,122\left(\mathrm{X}_{1}\right)+0,394\left(\mathrm{X}_{2}\right)+\mathrm{e}
$$

Berdasarkan persamaan tersebut, maka variabel atmosfer toko dan kesesuaian harga berpengaruh terhadap keputusan pembelian pada Temday Store Denpasar.

Diketahui konstanta besarnya 4,154 mengandung arti jika variabel Atmosfer Toko $\left(\mathrm{X}_{1}\right)$ dan Kesesuaian Harga $\left(\mathrm{X}_{2}\right)$ tidak berubah, maka Keputusan Pembelian (Y) tidak mengalami perubahan atau sama dengan 4,154.

a) $\beta_{1}=0,122$; berarti apabila variabel Atmosfer Toko $\left(X_{1}\right)$ menjadi lebih baik, maka akan mendorong Keputusan Pembelian (Y), dengan asumsi variabel bebas yang dianggap konstan.

b) $\beta_{2}=0,394$; berarti apabila variabel Kesesuaian Harga $\left(X_{2}\right)$ menjadi lebih baik, maka akan mendorong Keputusan Pembelian (Y), dengan asumsi variabel bebas yang dianggap konstan.

Tabel 10.

Hasil Uji Normalitas

\begin{tabular}{ccc}
\hline & & $\begin{array}{c}\text { Unstandardized } \\
\text { Residual }\end{array}$ \\
\hline$N$ & & 90 \\
Normal Parameters $^{a, b}$ & Mean & .0000000 \\
& Std. Deviation & 1.07570441 \\
Most Extreme & Absolute & .087 \\
Difference & Positive & .057 \\
Kolmogorov-Smirnov Z & Negative & -.087 \\
Asymp. Sig. (2-tailed) & & .825 \\
Sumber: Data diolah, 2016 & & .505 \\
\hline
\end{tabular}


Tabel 10, menunjukkan bahwa nilai Kolmogorov-Smirnov (K-S) adalah sebesar 0,825 dan nilai Asymp. Sig. (2-tailed) adalah sebesar 0,505. Nilai Asymp. Sig. (2-tailed) 0,505 >0,05, ini berarti menunjukkan bahwa residual dari model regresi yang berdistribusi normal.

Tabel 11.

Hasil Uji Multikolinearitas

\begin{tabular}{cccc}
\hline No & Variabel & Nilai Tolerance & Nilai VIF \\
\hline 1. & Atmosfer Toko & 0,564 & 1,773 \\
2. & Kesesuaian Harga & 0,564 & 1,773
\end{tabular}

Sumber: Data diolah, 2016

Tabel 11, nilai tolerance dari variabel atmosfer toko adalah sebesar 0,564 atau 56,4 persen dan kesesuaian harga sebesar 0,564 atau 56,4 persen. Nilai tersebut menunjukkan bahwa nilai tolerance masing-masing variabel lebih besar dari 10 persen. Nilai VIF dari variabel atmosfer toko dan kesesuaian harga sebesar 1,733; dan 1,733 dimana masing-masing variabel nilainya lebih kecil dari 10 yang berarti bahwa model regresi bebas dari multikolinearitas.

Tabel 12.

Hasil Uji Heteroskedastisitas

\begin{tabular}{clcl}
\hline No & Variabel & Sig. & Keterangan \\
\hline 1. & Atmosfer Toko & 0,385 & Bebas heteroskedastisitas \\
2. & Kesesuaian Harga & 0,358 & Bebas heteroskedastisitas \\
\hline
\end{tabular}

Sumber: Data diolah, 2016

Tabel 12, dapat diketahui bahwa nilai Sig. Atmosfer Toko dan Kesesuaian Harga lebih besar dari 0,05 . Hal ini berarti bahwa tidak terdapat pengaruh antara variabel bebas terhadap absolute residual, sehingga model yang dibuat tidak mengandung gejala heterokedastisitas. 
Tabel 13.

Hasil Uji-t

\begin{tabular}{clccc}
\hline No & Variabel & thitung & Signifikansi & tTabel \\
\hline 1. & Atmosfer Toko & 3,641 & 0,000 & 1,980 \\
2. & Kesesuaian Harga & 2,745 & 0,007 & 1,980 \\
\hline
\end{tabular}

Sumber: Data diolah, 2016

Tabel 13, dapat diketahui bahwa thitung sebesar 3,641 lebih besar dari $t_{\text {tabel }}$ sebesar 1,980 dengan nilai sig $0,000<\alpha(0,05)$ maka $\mathrm{H}_{0}$ ditolak. Hal ini berarti variabel atmosfer toko berpengaruh positif terhadap variabel keputusan pembelian konsumen pada Temday Store Denpasar.

Hasil penelitian ini mendukung penelitian sebelumnya yang dilakukan oleh Nofiawaty dan Yuliandi (2014) menyatakan bahwa hasil analisis menunjukan atmosfer toko mempunyai pengaruh yang signifikan terhadap keputusan pembelian. Penelitian ini sejalan dengan hasil yang dilakukan oleh Melisa (2012) menyatakan bahwa hasil analisis menunjukan desain dan tampilan toko berpengaruh signifikan terhadap keputusan pembelian ulang konsumen. Penelitian lain yang mendukung dilakukan oleh Hadi (2004) menunjukan bahwa atmosfer toko berpengaruh positif dan signifikan terhadap keputusan pembelian.

Tabel 13, dapat diketahui bahwa $t_{\text {hitung }}$ sebesar 2,745 lebih besar dari $t_{\text {tabel }}$ sebesar 1,980 dengan nilai sig $0,007<\alpha(0,05)$ maka $\mathrm{H}_{0}$ ditolak. Hal ini berarti variabel kesesuaian harga berpengaruh positif terhadap variabel keputusan pembelian konsumen pada Temday Store Denpasar.

Hasil penelitian ini mendukung penelitian sebelumnya yang dilakukan oleh Hariadi dan Martoatmodjo (2013) yang menunjukan bahwa kesesuaian harga berpengaruh positif terhadap keputusan pembelian konsumen. Penelitian 
selanjutnya yang dilakukan oleh Wibowo dan Karimah (2012) menyatakan bahwa harga memiliki pengaruh positif terhadap keputusan pembelian konsumen. Penelitian lain yang mendukung dilakukan oleh Purwati dkk. (2012) menyatakan bahwa hasil analisis menunjukan harga berpengaruh signifikan terhadap keputusan pembelian konsumen.

Terdapat temuan penelitian dengan kebijakan yang dapat dilakukan serta strategi pemasaran yang dapat diaplikasikan yaitu: 1) Pada variabel atmosfer toko, indikator kebersihan merupakan salah satu indikator yang memiliki rata-rata tertinggi dibandingkan dengan indikator lainnya. Bagi konsumen, kebersihan ruangan toko merupakan salah satu faktor yang mendorong konsumen berkunjung dan berbelanja pada Temday Store. Pihak Temday Store sebaiknya mempertahankan kebersihan yang ada diruangan toko, karena telah terbukti dapat mendorong keputusan pembelian pada konsumen. 2) Pada variabel kesesuaian harga, indikator kesesuaian harga dengan kualitas produk memiliki rata-rata lebih tinggi dibandingkan dengan yang lainnya. Bagi konsumen, harga yang ditawarkan oleh Temday Store sesuai dengan kualitas produk itu sendiri. Pihak Temday Store sebaiknya mempertahankan kesesuaian harga dengan kualitas produk karena terbukti dapat membuat konsumen puas berbelanja dan melakukan pembelian ulang pada Temday Store. 


\section{SIMPULAN DAN SARAN}

Berdasarkan pembahasan hasil penelitian ini maka dapat ditarik simpulan sebagai berikut. 1) Atmosfer toko berpengaruh positif dan signifikan terhadap keputusan pembelian konsumen pada Temday Store Denpasar. Indikator kebersihan merupakan salah satu indikator yang memiliki rata-rata tertinggi dibandingkan dengan indikator lainnya yang dapat mendorong konsumen berkunjung dan berbelanja pada Temday Store. Hal ini berarti, semakin baik atmosfer toko yang ada di area Temday Store dapat mendorong keputusan pembelian pada konsumen. 2) Kesesuaian harga berpengaruh positif dan signifikan terhadap keputusan pembelian konsumen pada Temday Store Denpasar. Indikator kesesuaian harga dengan kualitas produk memiliki rata-rata lebih tinggi dibandingkan dengan yang lainnya karena terbukti dapat membuat konsumen puas berbelanja dan melakukan pembelian ulang pada Temday Store. Hal ini berarti, semakin sesuai harga yang ditawarkan oleh Temday Store dapat mendorong keputusan pembelian pada konsumen.

Berdasarkan pembahasan hasil penelitian dan simpulan di atas, maka saran yang dapat diberikan adalah sebagai berikut. 1) Pada variabel atmosfer toko, indikator teknologi memiliki rata-rata terkecil dibandingkan dengan indikator lainnya. Pihak Temday Store disarankan untuk menambah teknologi dan fasilitas pembayaran sehingga mempermudah konsumen dalam melakukan transaksi pembayaran. 2) Pada variabel kesesuaian harga, indikator keterjangkauan harga memiliki rata-rata lebih kecil dibandingkan dengan indikator kesesuaian harga dengan kualitas produk. Pihak Temday Store disarankan untuk lebih 
mempertimbangkan dalam menawarkan harga pada suatu produk sehingga harga yang ditawarkan terjangkau oleh konsumen. 3) Peneliti selanjutnya dapat menggunakan teknik analisa yang beragam, sehingga hasil penelitian dapat dilihat dari berbagai sudut pandang dan berbagai kalangan. 4) Peneliti juga dapat mempertimbangkan variabel lain yang dapat mempengaruhi keputusan pembelian.

\section{REFERENSI}

Bahri. 2011. "Analisis pengaruh Harga, Pelayanan, Atmosfer Kenyamanan, Keragaman Produk dan Desain Toko terhadap Keputusan Pembelian Konsumen (Studi Kasus Pada Gardena Department Store)”.

Chen, Han-Shen dan Tsuifang Hsieh. 2011. "The effect of Atmosphere on Customer Perceptions and Customer Behavior responses in chain store Supermarkets". African Journal of Business Management, 5(24): h:10054-10066.

Fuad, Muhammad. 2009. "Store Atmosphere dan Perilaku Pembelian Konsumen di Toko Buku Gramedia Malang”.

Hariadi, Doni dan Soebari Martoatmodjo. 2013. "Pengaruh Produk, Harga, Promosi dan Distribusi terhadap Keputusan Pembelian konsumen pada Produk Projector Microvision”. Jurnal Ilmu dan Riset Manajemen, 1(1): h:67-87.

Hedrick, Natalie, Harmen Oppewal, Michael Beverland. 2002. "Store Atmosphere effects on Customer Perceptions of the Retail Sales Person". h:96-97.

Irawan Ardi, Achmad. 2010. "Pengaruh Store Atmosphere (Suasana Toko) terhadap Keputusan Pembelian (Survei Pada Konsumen yang berbelanja di Giant Hypermarket, Mall Olympic Garden Malang)". Skripsi. Sarjana Fakultas Ilmu Administrasi, Malang.

Karmela F, Lili dan Jujun Junaedi. 2009. "Pengaruh Store Atmosphere terhadap Minat Beli Konsumen pada Toserba Griya Kuningan”. 5(9): h:94-106.

Kenesei, Zsofia and Sarh Todd. 2003. "The Use of Price in the Purchase Decision". Journal of Empirical Generalisations in Marketing Science 8. h:1-21. 
Kotler, Philip dan Gary Armstrong. 2008. Prinsip-prinsip Pemasaran. Jilid 1. Edisi ke 12. Jakarta : Erlangga.

Lubis, Nurbaity dan Martin. 2009. "Pengaruh Harga (Price) dan Kualitas Pelayanan (Service Quality) terhadap Kepuasan Pasien rawat inap di RSU Deli Medan”. Jurnal Manajemen Bisnis, 2(1): h:21-24.

Meldarianda, Resti dan Henky Lisan S. 2010. "Pengaruh Store Atmosphere terhadap Minat Beli Konsumen pada Resort Café Atmosphere Bandung”. Jurnal Bisnis dan Ekonomi, 17(2): h:97-108.

Melisa, Yuda. 2012. "Pengaruh Bauran Pemasaran Ritel terhadap Keputusan Pembelian Ulang Konsumen Mega Prima Swalayan Payakumbuh". Jurnal Manajemen, 1(1): h:1-20.

Nofiawaty dan Beli Yuliandi. 2014. "Pengaruh Store Atmosphere terhadap Keputusan Pembelian Konsumen Pada Outlet Nyenyes Palembang”. Jurnal Manajemen dan Bisnis Sriwijaya, 12(1): h:55-73.

Putra Eko, Nandi. 2011. "Analisis pengaruh Suasana Toko (Store Atmosphere) dan Lokasi terhadap Minat Beli Konsumen di Wadezig Distro Kota Padang”. Skripsi. Sarjana Fakultas Ekonomi Universitas Andalas, Padang.

Purwati, Heri Setiawan dan Rohmawati. 2012. "Pengaruh Harga dan Kualitas Produk terhadap Keputusan Pembelian Motor Honda Matic Beat (Studi Kasus Pada PT. Nusantara Solar Sakti)". Jurnal Ekonomi dan Informasi Akuntansi, 2(3): h:260-277.

Schiffman, Leon dan Leslie Lazar Kanuk. 2008. Perilaku Konsumen. Edisi ke 7. Jakarta : Indeks.

Suprapti Sri, Ni Wayan. 2010. Perilaku Konsumen. Denpasar: Udayana University Press.

Sugiyono. 2014. Metode Penelitian Bisnis. Bandung: Alfabeta.

Suti, Intan. 2010. "Pengaruh Kualitas Produk, Harga dan Promosi terhadap Keputusan Pembelian Handphone Esia (Studi Kasus Pada Mahasiswa UIN Syarif Hidayahtullah Jakarta)". Skripsi Sarjana Fakultas Ekonomi dan Bisnis Universitas Negeri Islam Syarif Hidayahtullah, Jakarta.

Wibowo Ferry, Setyo dan Maya Puspita Karimah. 2012. "Pengaruh Iklan Televisi dan Harga terhadap Keputusan Pembelian Sabun Lux (Survei Pada Pengunjung Mega Bekasi Hypermall)". Jurnal Riset Manajemen Sains Indonesia, 3(1): h:1-15.

Wirawan, Nata. 2002. Statistik 2 (Statistic Inferensia) Untuk Ekonomi dan Bisnis. Denpasar : Keraras Emas. 